\title{
Gambaran Tingkat Pengetahuan Penyakit Ginjal Dan Terapi Diet Ginjal Dan Kualitas Hidup Pasien Hemodialisis Di Rumkital Dr. Ramelan Surabaya
}

\section{Description in the Level of Knowledge Regarding Kidney Disease and Renal Diet Therapy and Quality of Life among Hemodyalisis Patients in Dr Ramelan Naval Hospital, Surabaya}

\author{
Aniek Kurniawati*1, Adhiyanti Asikin ${ }^{2}$
}

\begin{abstract}
ABSTRAK
Latar Belakang: Kondisi pasien yang menjalani terapi hemodialisis akan memicu berbagai masalah seperti masalah fisik, psikologis, gaya hidup, dan perubahan sosial yang akan berdampak pada kualitas hidup pasien. Namun, dengan pengetahuan tentang penyakit ginjal dan terapi diet ginjal, yang dimiliki oleh seorang pasien gagal ginjal kronik akan mempengaruhi sikap dan perilaku hidup sehat dalam melaksanakan terapi hemodialisis dan terapi diet dengan benar.

Tujuan: Penelitian ini bertujuan untuk menganalisis hubungan tingkat pengetahuan dengan kualitas hidup pasien gagal ginjal kronik (GGK) yang menjalani terapi hemodialysis (HD).

Metode: Penelitian ini merupakan penelitian observasional analitik dengan pendekatan cross sectional. Sampel penelitian sebanyak 53 orang, diambil secara acak. Pengumpulan data melalui wawancara meliputi karakteristik pasien, tingkat pengetahuan dan skor kualitas hidup pasien GGK dengan HD. Analisa data yang digunakan dalam penelitian ini adalah uji statistik Spearman Correlation dengan $\mathrm{Cl}$ sebesar $95 \%(\alpha=0.05)$.

Hasil: Tingkat pengetahuan responden $62.3 \%$ termasuk dalam kategori baik. Sumber informasi yang diperoleh responden $100 \%$ berasal dari petugas kesehatan. Terdapat hubungan antara tingkat pengetahuan dengan kualitas hidup responden $(p=0.023)$. Berdasarkan domain kualitas hidup, kesehatan psikologis mempunyai hubungan dengan tingkat pengetahuan $(p=0.014)$, sedangkan kesehatan fisik $(p=0.125)$ dan hubungan sosial $(p=0.277)$ tidak ada hubungan dengan tingkat pengetahuan.

Kesimpulan: Kualitas hidup pasien GGK dengan HD dapat dipengaruhi dari tingkat pengetahuan, terutama kualitas hidup terkait kesehatan psikologis. Reran tenaga kesehatan sebagai sumber informasi, untuk itu perlu adanya usaha untuk meningkatkan ilmu pengetahuan seperti mengikuti seminar, workshop dan pelatihan terkait profesinya, sehingga diharapkan dapat memberikan informasi sesuai perkembangan ilmu yang terbaru..
\end{abstract}

Kata kunci: kualitas hidup, tingkat pengetahuan, gagal ginjal kronik 


\begin{abstract}
Background: Patients condition during haemodialysis therapy program would trigger multiple problems regarding physical and psychological condition, life style disruption, and spontaneous social changes which afflict quality of life. However, a knowledge of chronic kidney disease patients would influence healthy lifestyle attitude and behaviour in haemodialysis and diet therapies.

Objectives: The objective of this research was to analyze the relationship between knowledge and quality of life in chronic renal failure (CRF) patients with haemodialysis (HD) therapy.

Method: This research utilized analytical observational type with cross sectional approach. There were 53 patients as random samples. The data consisted of the characteristic, knowledge and quality of life score of CRF patients with HD therapy. Furthermore, the datas were analyzed through Spearman Correlation statistical test with $\mathrm{Cl}$ approximately $95 \%(\alpha=0,05)$.

Results: As many as 62.3\% of respondents were categorized as having a good quality. The entire of information source were obtained from medical workers. In addition. There was a positive relation between knowledges and quality of life $(p=0.023)$. However, based on quality of domain, only psychological health had significant relation with knowledges $(p=0.014)$. Meanwhile, significant relations cannot be shown between knowledges and physical health $(p=0.125)$ or social relation $(p=0.277)$ with it.

Conclusion: The quality of life of CRF with HD patients can be influenced by the level of knowledges, especially quality of life related to psychological health. There is And the role of health workers as a source of information, for it needs an effort to improve science such as attending seminars, workshops and training related profession, so it is expected to provide information according to the latest developments in science
\end{abstract}

Keywords: quality of life, level of knowledge, chronic renal failure

\author{
*Koresponden: \\ aniekkurniawati@gmail.com \\ ${ }^{1}$ Instalasi Gizi RSAL Dr. Ramelan Surabaya \\ ${ }^{2}$ Rumah Sakit Umum Daerah (RSUD) Dr. Soetomo, Surabaya
}

\section{PENDAHULUAN}

Gagal ginjal kronik menjadi masalah besar dunia karena sulit disembuhkan. Menurut World Health Organization (WHO) angka kejadian gagal ginjal di dunia secara global lebih dari 500 juta orang dan yang harus hidup dengan menjalani hemodialisis sekitar 1,5 juta orang. Berdasarkan data Indonesian Renal Registry (2015), tercatat 30.554 pasien aktif dan 21.050 pasien baru yang menjalani terapi hemodialisis. Pengguna HD adalah pasien dengan diagnosis GGK (89\%). Urutan penyebab gagal ginjal pasien yang mendapatkan hemodialisis berdasarkan data Indonesian Renal Registry tahun 2015, karena hipertensi (44\%), penyakit diabetik mellitus atau nefropati diabetik (22\%), kelainan bawaan atau Glomerulopati Primer (8\%), Pielonefritis kronik/PNC) (7\%), gangguan penyumbatan saluran kemih atau Nefropati Obstruksi (5\%), karena Asam Urat (1\%), penyakit Lupus (1\%) dan penyebab lainnya (8\%). ${ }^{1}$

Ginjal merupakan salah satu organ penting di dalam tubuh kita, yang berfungsi untuk menyaring (filtrasi) dan mengeluarkan zat-zat sisa metabolisme (racun) dari darah menjadi urin. Pada keadaan gagal ginjal kronis (Chronic Renal Failure) terjadi penurunan fungsi ginjal secara progresif dan tidak dapat pulih kembali. 
Upaya yang bisa dilakukan adalah dengan mempertahankan fungsi ginjal yaitu dengan terapi hemodialisis atau lebih dikenal dengan istilah cuci darah, yang dapat mencegah kematian tetapi tidak dapat menyembuhkan atau memulihkan fungsi ginjal secara keseluruhan. Selain itu pengobatan yang diperlukan oleh pasien gagal ginjal selain hemodialisis adalah transplantasi ginjal dan dialisis peritoneal. ${ }^{2}$

Hasil studi pendahuluan berdasarkan laporan jumlah pasien di Unit Hemodialisa Rumkital Dr. Ramelan Surabaya menyebutkan bahwa kunjungan pasien perhari yang melakukan hemodialisa mencapai 55- 57 kunjungan, dan jumlah kunjungan perbulan mencapai rata-rata 1020 kunjungan. Jumlah total pasien yang menjalani HD efektif di unit ini sebanyak 121 orang pada bulan Februari 2017. Selama 14 tahun sejak tahun 2003 kunjungan meningkat sebanyak 98,87\%. Pasien rata-rata menjalani hemodialisa sebanyak 2 kali seminggu selama 4-5 jam per kunjungan. Selain itu, pasien di unit ini ratarata merupakan pasien yang sudah lama menjalani hemodialisa, bahkan ada pasien yang rutin HD lebih dari 4 tahun. Akibat dari terapi hemodialisis dalam jangka waktu yang lama dapat menimbulkan penurunan nafsu makan, mual, muntah serta kehilangan protein dan vitamin, sehingga dapat menyebabkan gangguan status gizi. ${ }^{3}$ Menurut hasil studi yang dilakukan oleh Afshar, dkk ${ }^{4}$ menyatakan bahwa status gizi kurang dapat menyebabkan pasien mengalami gejala seperti lelah dan malaise, sakit kepala, kehilangan berat badan, kelemahan otot, infeksi berulang, penyembuhan luka yang lambat, serta gangguan tulang, hal ini dapat menyebabkan terjadinya penurunan kualitas hidup pada pasien hemodialisis. Oleh karena itu diperlukan pengaturan diet untuk mencapai status gizi yang baik. ${ }^{4}$ Upaya dalam melaksanakan terapi diet secara benar dan kontinyu, dengan meningkatkan pengetahuan dan pemahaman materi edukasi tentang penyakit ginjal dan terapi diet ginjal.

Kondisi pasien yang menjalani terapi hemodialisis akan memicu berbagai masalah seperti masalah fisik, psikologis, gaya hidup, dan perubahan sosial yang akan berdampak pada kualitas hidup pasien. ${ }^{5}$ Pada pasien dengan GGK terminal seringkali didapatkan health related quality of life (HRQOL) yang tidak baik dan memburuk setelah menjalani terapi dialisis. ${ }^{5,6,7} \mathrm{HRQOL}$ merupakan prediktor yang baik terhadap mortalitas dan prognosis pada pasien GGK. Penilaian HRQOL pada pasien GGK wajib dilakukan sebagai evaluasi terhadap efektivitas terapi dan prediksi komplikasi. $^{8}$

Adapun faktor-faktor yang mempengaruhi kualitas hidup antara lain usia, pendidikan, jenis kelamin, pekerjaan, dan status gizi. ${ }^{9}$ Tingkat pendidikan erat kaitannya dengan tingkat kesehatan. Karena masyarakat dengan tingkat pendidikan yang rendah akan tetap mempertahankan tradisi-tradisi yang berhubungan dengan makanan, sehingga sulit menerima informasi di bidang gizi dan bidang kesehatan lainnya. ${ }^{10}$ Tingkat pendidikan juga merupakan faktor yang mempengaruhi tingkat pengetahuan, dengan tingkat pendidikan yang tinggi maka akan semakin mudah untuk menerima konsep hidup sehat secara mandiri, kreatif dan berkesinambungan. ${ }^{11}$ Penelitian Ismail, dkk menunjukkan bahwa ada hubungan antara pendidikan, pengetahuan dan motivasi dengan kepatuhan diet pada pasien GGK. ${ }^{12}$

Gaya hidup atau perilaku yang tidak sehat seperti kebiasaan mengkonsumsi makanan cepat saji, kesibukan yang membuat stress, duduk seharian di kantor, sering minum kopi dan jarang minum air putih, merupakan faktor pemicu terjadinya penyakit ginjal. ${ }^{13}$ Menurut Notoatmodjo ${ }^{14}$, perilaku manusia terbagi menjadi 3 (tiga) domain yaitu pengetahuan, sikap dan tindakan. Dengan pengetahuan yang dimiliki oleh seorang pasien gagal ginjal kronik akan mempengaruhi sikap dan perilaku hidup sehat dalam melaksanakan terapi hemodialisis dan terapi diet dengan benar. ${ }^{15}$ Perubahan perilaku yang dilandasi pengetahuan, kesadaran dan sikap yang positif bersifat langgeng karena didasari oleh kesadaran mereka sendiri bukan karena paksaan. ${ }^{14}$

Tujuan dari penelitian ini untuk menganalisis hubungan tingkat pengetahuan dengan kualitas hidup pasien gagal ginjal 
kronik yang menjalani terapi hemodialisis di Rumkital Dr. Ramelan Surabaya. Manfaat dari penelitian ini selain sebagai bahan masukan informasi mengenai tingkat pengetahuan dan kualitas hidup pasien GGK yang menjalani terapi HD, sehingga dapat dijadikan sebagai bahan masukan untuk lebih meningkatkan kinerja dan profesionalisme tenaga kesehatan yang terkait, juga bermanfaat bagi responden untuk menambah wawasan, pengetahuan dan pemahaman responden mengenai penyakit ginjal dan terapi diet ginjal, sehingga diharapkan dapat menjalani terapi hemodialisis dan terapi diet dengan benar dan teratur.

\section{METODE}

Penelitian ini merupakan penelitian observasional analitik dengan pendekatan cross sectional.,yang dilaksanakan pada bulan April - Agustus 2017. Populasi dalam penelitian ini adalah pasien gagal ginjal yang menjalani terapi di Ruang Hemodialisis Rumkital Dr. Ramelan Surabaya pada bulan Januari - Maret 2017 yang berjumlah ratarata setiap bulan 121 pasien. Jumlah sampel ditentukan dengan menggunakan rumus Lameshow sehingga diperoleh sampel sebesar 53 pasien yang terpilih secara acak di unit Hemodialisa Rumkital Dr. Ramelan Surabaya. Pengumpulan data meliputi tingkat pengetahuan, tingkat pendidikan, pekerjaan, usia, sumber informasi tentang penyakit ginjal dan terapi diet ginjal yang dapat diperoleh melalui media maupun petugas kesehatan dan kualitas hidup . Instrumen yang digunakan yaitu kuesioner tingkat pengetahuan tentang penyakit ginjal dan tingkat pengetahuan tentang terapi diet ginjal, kuesioner SF 36 untuk mengetahui kualitas hidup pasien GGK dengan HD. ${ }^{16}$ Analisis data menggunakan uji Spearman Correlation.

Prosedur penelitian diawali dengan uji kelayakan etik No. 60/FC/KERS/2017, untuk menghindari kesalahan dan kerugian terhadap responden. Kemudian mengetahui jumlah populasi sebanyak 121 pasien dan diambil sebagai sampel sebanyak 53 pasien sesuai dengan kriteria inklusi. pasien dengan diagnosa GGK yang menjalani terapi HD minimal 1 kali, mampu membaca dan menulis, bersedia menjadi responden dan dapat diajak berkomunikasi. Pemilihan sampel dilakukan dengan menggunakan teknik lotre kemudian melakukan wawancara sesuai dengan kuesioner yang telah disiapkan, yang sebelumnya kuesioner tersebut telah divalidasi dan di uji realibilitasnya. Uji validitas dan realibilitas dilakukan terhadap 20 pasien GGK yang menjalani terapi hemodialisis di Rumkital Dr Ramelan Surabaya. Adapaun hasil validitas untuk kuesioner kualitas hidup diperoleh sebesar 0,449-0,852, kuesioner tingkat pengetahuan tentang penyakit ginjal diperoleh nilai validitas sebesar $0,452-0,747$ dan kuesioner tingkat pengetahuan tentang diet penyakit ginjal sebesar 0,466 - 0,707. Menurut Sugiyono, jika hasil uji $r$ hitung lebih besar dari $r$ tabel ( $r$ hitung $>0,3$ ) maka item pertanyaan tersebut dinyatakan valid dan sebaliknya. ${ }^{1}$ Demikian juga untuk hasil uji reliabilitas, jika nilai cronbach alpha $\geq 0,70$ maka instrumen yang akan digunakan reliabel. ${ }^{1}$ Adapun hasil reliabilitas untuk kuesioner kualitas hidup nilai cronbach alpha diperoleh sebesar 0,942, kuesioner tingkat pengetahuan tentang penyakit ginjal diperoleh nilai reliabilitas sebesar 0,756 dan kuesioner tingkat pengetahuan tentang diet penyakit ginjal sebesar 0,832 . Hal ini menunjukkan bahwa seluruh item pertanyaan kuesioner reiabel.

\section{HASIL DAN PEMBAHASAN}

Pasien gagal ginjal kronik yang menjalani terapi hemodialisa bisa bertahan hidup dengan menjalani terapi hemodialisa, namun masih menimbulkan permasalahan sebagai dampak dari terapi hemodialisa. ${ }^{17}$ Untuk mencapai kualitas hidup yang baik, maka perlu perubahan secara fundamental atas cara pandang pasien tentang hidup sehat yang harus dan bagaimana menjalaninya yang dapat terlihat pada perubahan sikap. Sedang perubahan sikap ini dipengaruhi beberapa faktor diantaranya adalah emosional/ psikologis, pengalaman pribadi dan tingkat pengetahuan. ${ }^{18}$

Sedang tingkat pengetahuan pasien gagal ginjal kronik dipengaruhi oleh faktor internal 
yang meliputi usia, tingkat pendidikan dan pekerjaan, faktor eksternal yang meliputi adalah faktor lingkungan, faktor sosial budaya dan sumber informasi yang bisa juga didapat dari proses konsultasi gizi. ${ }^{14}$

Berdasarkan karakteristik responden pada tabel 1 jenis kelamin responden pria lebih banyak daripada responden wanita yaitu sebanyak 30 orang $(56,6 \%)$ pria dan 23 orang $(43,4 \%)$ wanita. Hasil penelitian ini selaras dengan hasil penelitian Sufiana ${ }^{19}$ menunjukkan bahwa proporsi pasien GGK yang menjalani terapi HD jenis kelamin pria $68,3 \%$ lebih banyak dibandingkan wanita $31,7 \%$. Pada dasarnya dari beberapa literatur dijelaskan bahwa pasien gagal ginjal kronik tidak dipengaruhi oleh jenis kelamin, antara pria dan wanita memiliki resiko yang sama untuk menderita penyakit ginjal kronik. ${ }^{19}$

Besarnya proporsi jenis kelamin yang menderita gagal ginjal kronik yang menjalani terapi hemodialisis disebabkan karena peningkatan kreatinin dipengaruhi oleh massa otot dan terjadinya pemecahan otot (rhabdomiolisis). ${ }^{20}$ Pria cenderung memiliki lebh banyak massa otot sehingga kadar kreatinin darah lebih tinggi pria daripada wanita. ${ }^{20}$

Selain itu sesuai teori Price \& Wilson ${ }^{21}$ menurut etiologi gagal ginjal kronik yang terbanyak yaitu lebih didominasi oleh hipertensi. Berdasarkan hasil penelitian diperoleh bahwa $71,7 \%$ responden menderita hipertensi. Hipertensi dan gagal ginjal kronik mempunyai hubungan yang erat. Hipertensi dapat menjadi penyebab terjadinya gagal ginjal dan sebaliknya penyakit ginjal dapat menyebabkan hipertensi melalui mekanisme retensi natrium dan cairan. ${ }^{21}$

Berdasarkan hasil distribusi frekuensi usia (tabel 1), sebagian besar responden penelitian ini berada pada rentang usia $26-$ 55 tahun yaitu sebanyak 31 orang $(58,5 \%)$. Sesuai penelitian yang dilakukan oleh Nayana $\mathrm{SA}, \mathrm{dkk}^{5}$ menyatakan bahwa penyakit gagal ginjal disebabkan oleh penyakit ginjal dan penyakit gaya hidup seperti DM dan hipertensi, yang sebagian besar terlihat berhubungan dengan meningkatknya usia ${ }^{5}$. Berdasarkan teori Price \& Wilson ${ }^{21}$ pada penyakit ginjal kronik, nilai GFR turun dibawah nilai normal sebesar $125 \mathrm{ml} / \mathrm{menit}$. GFR juga menurun sesuai bertambahnya usia. Sesudah usia 30 tahun, nilai GFR menurun dengan kecepatan sekitar $1 \mathrm{ml} /$ menit/tahun. ${ }^{21}$

Menurut Guyton $\mathrm{AC}^{22}$ jumlah nefron yang terbentuk setelah lahir tidak dapat dibentuk lagi sehingga bila ada yang rusak jumlahnya akan menurun. Setelah usia 40 tahun, jumlah nefron umumnya akan berkurang $10 \%$ setiap 10 tahun sehingga pada usia 80 tahun jumlah nefron menjadi $40 \%$ lebih sedikit daripada ketika berusia 40 tahun. $^{22}$

Berdasarkan tabel 1 tingkat pendidikan, data yang diperoleh terbanyak pada tingkat SMA/sederajat yaitu sebanyak 26 orang $(49,1 \%)$ dan berjenjang perguruan tinggi sebanyak 15 orang (28,3\%). Menurut Notoatmodjo, ${ }^{15}$ pendidikan dapat mempengaruhi perilaku seseorang terhadap pola hidup terutama dalam motivasi sikap. Berdasarkan hasil pada penelitian ini bahwa tingkat pendidikan mempengaruhi perilaku seseorang dalam mencari perawatan dan pengobatan penyakit yang dideritanya, serta memilih dan memutuskan tindakan yang akan dan harus dijalani untuk mengatasi masalah kesehatannya. ${ }^{15}$

Berdasarkan tabel 1 pekerjaan, responden terbanyak adalah pegawai negeri (baik sipil, TNI maupun POLRI) sebanyak 14 orang $(26,4 \%)$ dan pegawai swasta yaitu 14 orang $(26,4 \%)$. Menurut Nursalam ${ }^{23}$ pekerjaan merupakan suatu kegiatan dengan tujuan untuk mencari nafkah. ${ }^{23}$ Penghasilan yang diperoleh juga digunakan untuk mendapatkan pelayanan kesehatan. $\mathrm{Hal}$ ini dapat diasumsikan bahwa responden yang menjalani terapi hemodialisis di rumkital Dr. Ramelan Surabaya mempunyai penghasilan yang cukup untuk mendapatkan pelayanan kesehatan Sesuai penelitian yang dilakukan oleh Lemos $\mathrm{dkk}^{24}$ menyatakan bahwa pendapatan keluarga merupakan faktor terpenting yang mempengaruhi kualitas hidup pasien hemodialisis. ${ }^{24}$

Kejadian gagal ginjal bisa terjadi karena faktor pekerjaan yang tanpa disadari dapat mempengaruhi pola hidup yang tidak sehat seperti mengkonsumsi minuman suplemen untuk mencegah kelelahan, timbul stress karena target yang harus dicapai bahkan 
kurang minum air putihpun merupakan faktor pemicu terjadinya penyakit ginjal kronik. ${ }^{13}$

Tabel 1.Distribusi Karakteristik Responden

\begin{tabular}{|c|c|c|}
\hline Karakteristik Responden & $\mathbf{n}$ & $\%$ \\
\hline \multicolumn{3}{|l|}{ Jenis Kelamin } \\
\hline Pria & 30 & 56,6 \\
\hline Wanita & 23 & 43,4 \\
\hline Jumlah responden & 53 & 100 \\
\hline \multicolumn{3}{|l|}{ Usia } \\
\hline $17-25$ tahun & 1 & 1,9 \\
\hline $26-55$ tahun & 31 & 58,5 \\
\hline$\geq 56$ tahun & 21 & 39,6 \\
\hline Jumlah responden & 53 & 100 \\
\hline \multicolumn{3}{|l|}{ Pendidikan } \\
\hline Tamat SD & 7 & 13,2 \\
\hline Tamat SMP & 5 & 9,4 \\
\hline Tamat SMA & 26 & 49,1 \\
\hline Tamat PT & 15 & 28,3 \\
\hline Jumlah responden & 53 & 100 \\
\hline \multicolumn{3}{|l|}{ Pekerjaan } \\
\hline PNS/TNI/POLRI/PURNA & 14 & 26,4 \\
\hline Pegawai Swasta & 14 & 26,4 \\
\hline Wiraswasta & 7 & 13,2 \\
\hline Lainnya & 5 & 9,5 \\
\hline IRT & 13 & 24,5 \\
\hline Jumlah responden & 53 & 100 \\
\hline \multicolumn{3}{|l|}{ Tingkat Pengetahuan } \\
\hline Kurang & 0 & 0 \\
\hline Cukup & 20 & 37,7 \\
\hline Baik & 33 & 62,3 \\
\hline Jumlah responden & 53 & 100 \\
\hline \multicolumn{3}{|l|}{ Kualitas Hidup } \\
\hline Kurang Berkualitas & 19 & 35,8 \\
\hline Berkualitas Baik & 34 & 64,2 \\
\hline Jumlah responden & 53 & 100 \\
\hline
\end{tabular}

Salah satu faktor yang mempengaruhi tingkat pengetahuan seseorang adalah bagaimana dia memperoleh suatu informasi. Berdasarkan hasil penelitian yang ditunjukan seperti pada tabel 2, sumber informasi yang diperoleh responden tentang penyakit dan terapi diet gagal ginjal $100 \%$ berasal dari petugas kesehatan, dan sumber informasi lainnya kurang dari $50 \%$ berasal dari keluarga/kerabat/teman, media elektronik dan sumber informasi dari media cetak. Asal sumber informasi yang diperoleh pasien tidak hanya dari petugas kesehatan tetapi dari media juga. Dan jawaban pasien bisa memilih lebih dari satu jawaban, sehingga pasien ada yg mendapat sumber informasi lebih dari satu sumber (misal bisa dari petugas kesehatan dan media elektronik atau dari media lainnya. Dan ada juga pasien yg memperoleh informasi hanya dari petugas saja). Berdasarkan hasil penelitian diperoleh bahwa tingkat pengetahuan pasien termasuk dalam kategori baik dapat dilihat pada tabel 1 .

Menurut Notoatmodjo ${ }^{14}$ menyatakan bahwa sumber informasi akan mempengaruhi bertambahnya pengetahuan seseorang dan sebagian besar pengetahuan manusia diperoleh dari penglihatan dan pendengaran. ${ }^{14}$ Sumber informasi ini diperoleh pada saat responden sedang menjalani terapi hemodialisa sehingga banyak responden yang lebih memilih untuk mendengarkan edukasi dari petugas kesehatan (ahli gizi, dokter dan perawat), Responden juga sering melakukan diskusi saat menunggu jadwal terapi hemodialisa dan ada juga yang berusaha untuk lebih memperdalam pengetahuan tentang penyakit dan terapi dietnya dengan mencari sumber informasi melalui media elektronik.

Berdasarkan data tingkat pengetahuan responden diperoleh dari hasil wawancara kuesioner pengetahuan tentang penyakit ginjal kronik yang memuat 10 item pertanyaan multiple choice dan pengetahuan tentang terapi diet penyakit ginjal yang memuat 15 pertanyaan benar salah. Responden dikatakan memiliki pengetahuan baik apabila skor yang didapatkan 76 - 100\%, dikatakan cukup jika skor yang didapatkan $56-75 \%$ dan responden yang mendapatkan skor $<56 \%$ dikatakan pengetahuan kurang baik. ${ }^{18}$ Adapun hasil yang diperoleh menunjukkan bahwa tingkat pengetahuan responden secara umum termasuk dalam kategori baik sebanyak 33 orang $(62,3 \%)$ dan dalam kategori cukup sebanyak 20 orang $(37,7 \%)$, seperti yang disajikan pada tabel 1 . 
Tabel 2. Distribusi Sumber Informasi yang Diperoleh Responden

\begin{tabular}{lcccccc}
\hline \multirow{2}{*}{ Sumber Informasi } & \multicolumn{3}{c}{ Jawaban Responden } & \multicolumn{2}{c}{ Total } \\
\cline { 2 - 7 } & \multicolumn{3}{c}{ Ya } & \multicolumn{2}{c}{ Tidak } & \multicolumn{2}{c}{} \\
\cline { 2 - 7 } & $\mathbf{n}$ & $\mathbf{n}$ & $\mathbf{n}$ & $\mathbf{n}$ \\
\hline Petugas Kesehatan & 53 & 100 & 0 & 0 & 53 & 100 \\
\hline Keluarga/Teman/Kerabat & 22 & 41,5 & 31 & 58,5 & 53 & 100 \\
\hline Media Elektronika & 19 & 35,8 & 34 & 64,2 & 53 & 100 \\
\hline Media Cetak & 5 & 9,4 & 48 & 90,6 & 53 & 100 \\
\hline
\end{tabular}

Berdasarkan data tingkat pendidikan responden terbanyak adalah tingkat SMA/ sederajat dan diikuti dengan yang berpendidikan perguruan tinggi, sehingga memudahkan responden untuk mendapatkan informasi baru. Menurut Notoatmodjo ${ }^{25}$ menjelaskan bahwa semakin tinggi pendidikan semakin tinggi pula pengetahuan. Akan tetapi pernyataan tersebut tidak terbukti pada penelitian ini. Hal ini dapat dilihat dari tingkat pengetahuan responden yang termasuk dalam kategori kurang sebanyak $0 \% .{ }^{25}$

Menurut $\mathrm{Azwar}^{26}$ usia dan pengalaman juga mempengaruhi tingkat pengetahuan seseorang. Karena dengan usia yang semakin matang mempengaruhi daya tangkap dan pola pikir seseorang, sehingga pengetahuan yang diperolehnya semakin membaik. Sedangkan pengalaman sebagai sumber pengetahuan adalah suatu cara untuk memperoleh kebenaran pengetahuan dengan cara mengulang kembali pengetahuan yang diperoleh dalam memecahkan masalah yang dihadapi masa lalu. ${ }^{26}$

Kondisi pasien yang menjalani terapi hemodialisis akan memicu berbagai masalah seperti masalah fisik, psikologis, gaya hidup, dan perubahan sosial yang akan berdampak pada kualitas hidup pasien. Menurut WHO kualitas hidup terbagi dalam 4 domain yaitu kesehatan fisik, kesehatan psikologis, hubungan sosial dan lingkungan. Kesehatan fisik ini berhubungan dengan kesakitan (rasa nyeri) dan kegelisahan, energi dan kelelahan, mobilitas, tidur dan istirahat, aktifitas kehidupan sehari-hari, dan kapasitas kerja.

Berdasarkan hasil penelitian pada tabel 3 diperoleh $75,47 \%$ responden menyatakan tidak merasakan nyeri setelah melakukan terapi hemodialisis, dan sisanya merasakan nyeri. Munculnya rasa nyeri pada beberapa responden ini mengatakan pada awal melakukan terapi hemodialisis dan pada saat mengalami kebocoran saat menjalani hemodialisis, sehingga harus dilakukan pemasangan ulang. Dan jika dilihat dari hasil rata-rata skor rasa nyeri yang tidak dialami responden lebih tinggi, hal ini menyatakan bahwa kuaitas hidup responden termasuk dalam kategori baik.

Berdasarkan hasil penelitian kualitas hidup terkait energi dan kelelahan, diperoleh nilai skor rata-rata 56,51 (pada tabel 3), hal ini termasuk dalam kategori kualitas hidup yang baik. Lebih dari $50 \%$ responden menyatakan masih mempunyai semangat yang tinggi untuk melakukan aktifitas dan mempunyai semangat untuk hidup lebih baik. Namun ada juga responden yang merasa mudah lelah dan terkadang muncul rasa bosan untuk melakukan terapi hemodialisis. Perasaaan mudah lelah ini disebabkan akibat terjadinya anemia yang sering dialami oleh responden. Seperti yang terdapat pada hasil penelitian Nurcahyati ${ }^{3}$ terhadap 95 penderita yang menjalani HD rutin di RSI Fatimah Cilacap dan RSUD Banyumas sebanyak $61 \%$ menderita anemia. ${ }^{3}$ Timbulnya anemia disebabkan karena menurunnya produksi eritropoetin akibat kerusakan ginjal. ${ }^{17}$

Rata-rata skor kualitas hidup terkait mobilitas dan aktifitas sehari-hari adalah 45,09 (pada tabel 3), menunjukkan bahwa kualitas hidup responden termasuk dalam kategori kurang berkualitas. Ini berarti bahwa kemampuan responden untuk melakukan aktifitas sehari-hari sudah mengalami penurunan. Kegagalan fungsi organ pada responden yang menjalani hemodialisis mengakibatkan perubahan fisik berupa ketidakmampuan melakukan pekerjaan seperti sediakala dan karena keterbatas serta 
Tabel 3. Distribusi Rata-rata Skor Kualitas Hidup Responden

\begin{tabular}{lccccc}
\hline \multicolumn{1}{c}{ Rata-rata Skor } & N & $\begin{array}{c}\text { Nilai } \\
\text { Minimal }\end{array}$ & $\begin{array}{c}\text { Nilai } \\
\text { Maksimal }\end{array}$ & Mean & $\begin{array}{c}\text { Std } \\
\text { Deviation }\end{array}$ \\
\hline Nyeri Tubuh & 53 & 10 & 100 & 81,08 & 27,624 \\
\hline Fungsi Fisik (Mobilitas dan Aktifitas sehari-hari) & 53 & 0 & 100 & 45,09 & 26,008 \\
\hline Kapasitas Bekerja/ Keterbatasan Fisik & 53 & 0 & 75 & 41,51 & 19,577 \\
\hline Energi dan Kelelahan (Vitalitas) & 53 & 10 & 100 & 56,51 & 26,102 \\
\hline Kesehatan secara Umum & 53 & 12,5 & 83,3 & 47,25 & 22,718 \\
\hline Hubungan Sosial & 53 & 0 & 100 & 62,97 & 32,053 \\
\hline $\begin{array}{l}\text { Keterbatasan Emosional (cara berpikir dan } \\
\text { konsentrasi) }\end{array}$ & 53 & 0 & 100 & 81,76 & 25,792 \\
\hline Kesehatan Mental (afek positif dan negative) & 53 & 24 & 100 & 75,62 & 19,631 \\
\hline
\end{tabular}

Tabel 4. Hubungan Tingkat Pengetahuan Dengan Kualitas Hidup Responden

\begin{tabular}{|c|c|c|c|c|c|c|c|c|}
\hline \multirow{3}{*}{$\begin{array}{c}\text { Tingkat } \\
\text { Pengetahuan }\end{array}$} & \multicolumn{4}{|c|}{ Kualitas Hidup } & & & \multirow{3}{*}{$\begin{array}{l}\text { Koefisien } \\
\text { korelasi }\end{array}$} & \multirow{3}{*}{ Nilai $p$} \\
\hline & \multicolumn{2}{|c|}{$\begin{array}{c}\text { Kurang } \\
\text { Berkualitas }\end{array}$} & \multicolumn{2}{|c|}{$\begin{array}{c}\text { Berkualitas } \\
\text { Baik }\end{array}$} & \multicolumn{2}{|c|}{ Total } & & \\
\hline & $n$ & $\%$ & $n$ & $\%$ & $n$ & $\%$ & & \\
\hline Cukup & 11 & 55,0 & 9 & 45,0 & 20 & 100 & 0,311 & 0,023 \\
\hline Baik & 8 & 24,2 & 25 & 75,8 & 33 & 100 & & \\
\hline
\end{tabular}

kelemahan fisik membuat responden tergantung terhadap orang lain.

Hasil tersebut juga berhubungan dengan hasil penelitian kualitas hidup yang terkait dengan kapasitas bekerja responden, seperti pada tabel 3 diperoleh bahwa rata-rata skor kapasitas bekerja responden adalah 41,51 yang berarti bahwa kualitas hidup responden terkait kapasitas bekerja termasuk dalam kategori kurang berkualitas.

Berdasarkan hasil wawancara selama penelitian diperoleh bahwa masih ada beberapa responden yang masih aktif bekerja yaitu pegawai negeri sipil dan militer, sedang sebagian responden yang bekerja sebagai pegawai swasta masih ada juga yang bertahan untuk melakukan pekerjaannya dengan kebijakan yang telah diberikan oleh pimpinan, dan untuk yang wiraswasta lebih memilih untuk tidak bekerja sehingga diteruskan oleh anak-anaknya. Responden yang masih bekerja mempunyai tujuan agar tetap bisa beraktifitas dan tetap memiliki sumber penghasilan.

Hasil penelitian Septiwi $\mathrm{C}^{27}$ menyatakan bahwa $85,7 \%$ responden yang bekerja memiliki kualitas hidup yang baik, karena dengan bekerja responden mampu menjalankan perannya yang tentunya akan berdampak pada peningkatan harga diri dan kualitas hidupnya serta meminimalkan konflik peran akibat perubahan kondisi fisik responden. ${ }^{27}$

Hasil penelitian ini berkorelasi dengan penelitian yang dilakukan oleh Teixera $\mathrm{dkk}^{28}$ yang menyatakan bahwa pasien Gagal Ginjal Kronik mengalami disfungsi otot. Gangguan ini dikarenakan beberapa faktor yang terkait dengan penyakit ginjal seperti penurunan asupan protein dan kalori, terjadi atrofi otot dan ketidakseimbangan protein di dalam tubuh, sehingga terjadi penurunan kemampuan dan kapasitas responden untuk melakukan aktifitas. ${ }^{28}$

Kesehatan psikologis ini berhubungan dengan emosional dan kesehatan mental yang meliputi pengaruh perasaan positif dan negatif, pemikiran pembelajaran, daya ingat dan konsentrasi, gambaran tubuh dan penampilan, serta penghargaan terhadap diri sendiri.

Kualitas hidup juga dipengaruhi oleh gangguan psikologis yang terkait dengan munculnya rasa cemas dan depresi, yang diekspresikan dengan munculnya perasaan 
negatif. Menurut Farida ${ }^{29}$ Semakin tinggi rasa cemas dan depresi maka kualitas hidup semakin rendah. ${ }^{29}$ Stress dapat menurunkan konsentrasi dan menghambat kemampuan kerja seseorang, berdasarkan hasil penelitian tentang keterbatasan emosional responden diperoleh bahwa lebih dari $50 \%$ responden masih dapat mengendalikan diri dalam melakukan aktifitas sehari-hari dan mampu menyelesaikan pekerjaan dengan baik. sedang hasil skor rata-rata diperoleh adalah 81,76 , ini berarti bahwa kualitas hidup responden terkait keterbatasan emosional termasuk dalam kategori baik.

Hasil kesehatan mental dalam penelitian ini diungkapkan responden dengan munculnya perasaan negatif (yaitu rasa tertekan, gugup, putus asa dan sedih) dan perasaan positif (yaitu perasaan tenang dan damai serta perasaan riang), dari hasil wawancara diperoleh bahwa lebih dari 50\% responden tidak pernah merasakan perasaan negatif dan dari nilai skor rata-rata diperoleh 75,62 . Hasil ini menunjukkan bahwa kualitas hidup responden terkait kesehatan mental termasuk dalam kategori baik. Seperti hasil penelitian Septiwi $C^{27}$ yang menunjukkan bahwa $64,9 \%$ responden yang mengalami depresi ringan mempunyai kualitas hidup yang baik. ${ }^{27}$

Kualitas hidup dilihat dari aspek hubungan sosial terdiri dari hubungan personal, aktivitas seksual, dan dukungan sosial. Berdasarkan hasil penelitian diperoleh bahwa kurang dari $50 \%$ responden menyatakan bahwa kesehatannya tidak mengganggu aktifitas sosial, sehingga responden masih bisa melakukan interaksi sosial dengan lingkungannya. Tetapi lebih dari $50 \%$ responden sudah membatasi aktifitas sosialnya, hal ini disebabkan karena responden merasa mudah capek jika beraktifitas dan merasa adanya keterbatasan untuk melakukan aktifitas sendiri sehingga tergantung pada orang lain.

Berdasarkan hasil penelitian menunjukkan bahwa sebagian besar kualitas hidup responden termasuk dalam kategori berkualitas baik. Penelitian ini selaras dengan hasil penelitian Fitria $^{30}$ bahwa responden dengan kualitas hidup yang baik sebanyak $60,9 \%$ dan yang kurang berkualitas hidupnya sebanyak $39,1 \% .{ }^{30} \mathrm{Hal}$ ini dapat membuktikan bahwa terapi hemodialisis merupakan terapi untuk memaksimalkan kualitas hidup responden.

Namun dalam hasil penelitian ini masih ada responden yang kualitas hidupnya kurang berkualitas yaitu sebesar $35,8 \%$, hal ini juga berhubungan dengan pengetahuan yang dimilikinya. Meskipun pengetahuan yang diberikan sama, namun tingkat pemahaman yang berbeda-beda antar responden yang menyebabkan pengetahuan mereka berbeda pula.

Berdasarkan hasil analisis hubungan antara tingkat pengetahuan tentang ginjal dan terapi diet ginjal dengan kualitas hidup responden seperti pada tabel 4 , menunjukkan bahwa responden dengan tingkat pengetahuan cukup mempunyai kualitas hidup kurang. Sedang dari responden dengan tingkat pengetahuan baik mempunyai kualitas hidup baik ( $p=0,023<0,05)$. Maka dapat disimpulkan bahwa ada hubungan antara tingkat pengetahuan dengan kualitas hidup pasien hemodialisis di Rumkital Dr. Ramelan Surabaya. Hubungan tersebut searah yang artinya semakin baik tingkat pengetahuan responden maka semakin baik pula tingkat kualitas hidup responden.

Bertambahnya pengetahuan responden akan mempengaruhi perubahan sikap dan perilaku responden dalam mengambil keputusan untuk melaksanakan terapi hemodialisa dan terapi pengobatan termasuk dalam pelaksanaan terapi diet yang harus dijalani. Hasil penelitian ini selaras dengan penelitian yang dilakukan oleh Kamalludin \& Rahayu ${ }^{31}$. Pada penderita yang mempunyai pengetahuan yang lebih luas memungkinkan pasien itu dapat mengontrol dirinya dalam mengatasi masalah yang di hadapi, mempunyai rasa percaya diri yang tinggi, berpengalaman, dan mempunyai perkiraan yang tepat bagaimana mengatasi kejadian serta mudah mengerti tentang apa yang dianjurkanoleh petugas kesehatan, akan dapat mengurangi kecemasan sehingga dapat membantu individu tersebut dalam membuat keputusan. ${ }^{31}$ Hasil penelitian ini didukung dengan teori Notoatmodjo ${ }^{15}$, dimana pengetahuan atau kognitif merupakan domain 
yang sangat penting untuk terbentuknya suatu tindakan,perilaku yang didasari pengetahuan akan lebih langgeng dari pada yang tidak didasari pengetahuan. ${ }^{15}$

\section{KESIMPULAN}

Kualitas hidup pasien GGK termasuk dalam kategori baik, hal ini salah satunya dipengaruhi oleh tingkat pengetahuan pasien yang baik. Tingkat pengetahuan ini juga dipengaruhi oleh tingkat pendidikan dan sumber informasi yang cukup banyak yang diperoleh secara kontinyu, sehingga dapat meningkatkan pengetahuan pasien.

Sumber informasi yang diperoleh berasal dari petugas kesehatan. Oleh karena itu petugas kesehatan diupayakan berusaha untuk meningkatkan ilmu pengetahuan seperti mengikuti seminar, workshop dan pelatihan terkait profesinya, sehingga diharapkan dapat memberikan informasi sesuai perkembangan ilmu yang terbaru.

Pada penelitian ini didapatkan bahwa tingkat pengetahuan mempengaruhi kualitas hidup pasien terutama pada kesehatan psikologis, sehingga diharapkan bagi peneliti berikutnya perlu melakukan penelitian tentang faktor-faktor yang mempengaruhi kesehatan psikologis pada pasien gagal ginjal kronik yang menjalani terapi hemodialisis, serta dapat mengetahui secara jelas masalah apa saja yang timbul akibat proses hemodialisis.

Kelemahan pada penelitian ini pada saat wawancara peneliti maupun responden kurang merasa nyaman, karena tempat tidur yang digunakan saat terapi HD sangat berdekatan, sehingga responden merasa kikuk saat menjawab pertanyaan. Selain itu karena pasien lain mendengar sehingga ada yang ikut mendengarkan kegiatan pengambilan data.

\section{ACKNOWLEDGEMENT}

Penulis mengucapkan terimakasih atas partisipasi pasien di RSAL Dr. Ramelan Surabaya dalam penelitian ini.

\section{REFERENSI}

1. Sugiyono. Metode Penelitian Pendidikan. (Alfabeta, 2011).

2. Black, J. M. \& Hawks, J. H. Keperawatan medikal bedah: manajemen klinis untuk hasil yang diharapkan. (2014).

3. Nurcahyati, S. Analisis factor -faktor yang berhubungan dengan kualitas hidup pasien penyakit ginjal kronik yang menjalani hemodialisis di Rumah Sakit Islam Fatimah Cilacap dan Rumah Sakit Umum Banyumas. (Universitas Indonesia, 2014).

4. Afshar R, Sanavi S, I. K. Assessment of Nutritional Status in Patients Undergoing Maintenance Hemodialysis: Single-Center Study from Iran. Saudi J. Kidney Dis. Transplant. 121, 691-695 (2008).

5. Nayana, S. A. et al. A cross sectional study on assessment of health related quality of life among end stage renal disease patients undergoing hemodialysis. Clin. Epidemiol. Glob. Heal. 5, 148-153 (2017).

6. Tsai, Y.-C. et al. Quality of life predicts risks of end-stage renal disease and mortality in patients with chronic kidney disease. Nephrol. Dial. Transplant. 25, 1621-1626 (2010).

7. Han, S. S. et al. Quality of life and mortality from a nephrologist's view: A prospective observational study. $B M C$ Nephrol. 10, 1-7 (2009).

8. (CDC), C. for D. C. and P. CDC 24/7: Saving Protecting People. (2017). Available at: https://www.cdc.gov/hrqol/concet.htm . (Accessed: 18th March 2017)

9. Yuwono. Kualitas Hidup Menurut Spitzer pada Penderita Gagal Ginjal Terminal yang Menjalani Hemodialisa di Unit Hemodialisis RSUP Dr. Kariadi Semarang. (Universitas Diponegoro Semarang, 2010).

10. Suhardjo. Berbagai Cara Pendidikan Gizi. (PT Bumi Aksara, 2003). 
11. Rachmawati, Y., Perwitasari, D.A., A. Validasi Kuesioner Sf-36 Versi Indonesia Terhadap Pasien Hipertensi Di Puskesmas Yogyakarta. J. Farm. Indones. 11, 14-25 (2014).

12. Ismail., Hasanudin., Bahar, B. Hubungan pendidikan, pengetahuan dan motivasi dengan kepatuhan diet pada pasien gagal ginjal kronik di Rumah Sakit Umum Pusat dr.Wahidin Sudirohusodo Makassar. J. Ilm. Kesehat. Diagnosis 1, 1-8 (2012).

13. Aroem, H. . Gambaran Kecemasan Dan Kualitas Hidup Pada Pasien Yang Menjalani Hemodialisa. (Universitas Muhammadiyah Surakarta, 2015).

14. Notoatmodjo, S. Promosi Kesehatan dan Perilaku Kesehatan. (Rineka Cipta, 2012).

15. Notoatmodjo, S. Pendidikan dan perilaku Kesehatan. (2007).

16. Ron D. Hays, JOel D Kallich, Donna L Mapes, Stephen Joel Coons, Naseem Amin, W. B. C. and C. K. Kidney Disease Quality of Life Short Form. Version 1.3. A Manual for Use and Scoring. Rand 139

(1997). doi:10.5747/cv2010.v02.n2.v032

17. Beiber, S.D. dan Himmelfarb, J. Hemodialysis.In: Schrier's Disease of the Kidney. (Lippincott Williams \& Wilkins, 2013).

18. Wawan, A., Dewi, M. Teori dan Pengukuran Pengetahuan, Sikap dan Perilaku Manusia. (Nuha Medika, 2010).

19. Sufiana PD, Diyah CA, S. Hubungan Lamanya Hemodialisa dengan Kualitas Hidup Pasien Gagal Ginjal Di RS PKU Muhammadiyah Yogyakarta. (STIKES Aisyiyah Yogyakarta, 2015).

20. National Kidney Foundation. K/DOQI Clinical Practice Guidelines for Chronic Kidney Disease: Evaluation, Clasification and Stratification. Am J Kidney Dis. 39, (2002).
21. Price S.A, dan Wilson, L. M. Patofisiologi "Konsep Klinis Proses-Proses Penyakit. (Penerbit Buku Kedokteran EGC, 2005).

22. Guyton, A.C, Hall, J. . Buku Ajar Fisiologi Kedokteran Edisi 11. (Penerbit Buku Kedokteran EGC, 2008).

23. Nursalam. Konsep dan Penerapan Metodologi Penelitian IImu Keperawatan. (Salemba Medika, 2008).

24. Lemos, C. F., Rodrigues, M. P. \& Veiga, J. R. P. Family income is associated with quality of life in patients with chronic kidney disease in the pre-dialysis phase: a cross sectional study. Health Qual. Life Outcomes 13, 202 (2015).

25. Notoatmodjo, S. Metodologi Penelitian Kesehatan. (Rineka Cipta, 2010).

26. Azwar, S. Sikap Manusia teori dan pengukurannya. (Pustaka Pelajar Offset, 2009).

27. Septiwi, C. Hubungan Antara Adekuasi Hemodialisis Dengan Kualitas Hidup Pasien Hemodialisis Di Unit Hemodialisis RS Prof. Dr. Margono Purwokerto. (Universitas Indonesia, 2010).

28. Teixeira, C. G. et al. Impact of chronic kidney disease on quality of life, lung function, and functional capacity. J. Pediatr. (Rio. J). 90, 580-586 (2014).

29. Farida, A. Pengalaman klien hemodialisis terhadap kualitas hidup dalam konteks asuhan keperawatan di RSUP Fatmawati Jakarta. (Universitas Indonesia, 2010).

30. Fitria, M. Hubungan Status Gizi Dengan Kualitas Hidup Pada Pasien Hemodialisis Di Rs PKU Muhammadiyah Unit II Yogyakarta. (STIKES Aisyiyah Yogyakarta., 2015).

31. Kamaluddin, R. \& Rahayu, E. Analisis Faktor-Faktor yang Mempengaruhi Kepatuhan Asupan Cairan pada Pasien Gagal Ginjal Kronik dengan Hemodialisis di RSUD Prof. Dr. Margono Soekarjo Purwokerto. J. Keperawatan Soedirman 4, 20-25 (2009). 